\title{
Covid-19 Pandemi Sürecinin Türk Yargı Sistemine Etkileri ${ }^{*}$
}

\author{
The Impact of the Covid-19 Pandemic Process on the Turkish Judical System
}

Seyyal YILDIRIMVURAN

Avukat, Devlet Arşivleri Başkanlığ

av.seyyalyildirimvuran@gmail.com

https://orcid.org/0000-0002-0456-2073
Makale Başvuru Tarihi: 29.10.2020

Makale Kabul Tarihi: 24.12.2020

Makale Türü: Araştırma Makalesi

\author{
Ulaş Koray MiLANLIOĞLU \\ Öğretim Görevlisi, Van Yüzüncü Yıl Üniversitesi, İktisadi ve İdari Bilimler Fakültesi Kamu Yönetimi Bölümü Hukuk \\ Bilimleri Anabilim Dall \\ koraymilanlioglu@yyu.edu.tr \\ https://orcid.org/0000-0001-6843-9533
}

\author{
Suat ÇAKAN \\ Avukat, Van Barosu \\ suatcakan@yahoo.com \\ https://orcid.org/0000-0002-2825-6230
}

\begin{abstract}
ÖZET
Anahtar

Kelimeler:

Dijital

Hukuk,

Covid 19,

Adalet,

Mevzuat,

Yargl Sistemi,

Bu çalışma ile ilk olarak Çin'in Wuhan kentinde deniz hayvanları pazarından yayıldı̆̆ı düşünülen ve Birleşmiş Milletlere bağlı Dünya Sağllk Örgütü'nün 'pandemi' olarak duyurduğu yeni tip korona virüsünün küresel nitelikte afet boyutuna çıkmasl, salgına yönelik etkili bir tedavinin bulunmaması; aşı yönteminin uzun süreçlerde tamamlanması, sosyal yaşamda kemikleşen ilişkilerin varlı̆̆l, alışkanlık haline gelen yaşam şekilleri karşısında yönetimin aldı̆̆ tedbirler hakkında değerlendirme yapılmıştır. Aynı zamanda, tüm dünyaya yayılan salgın ile mücadeleyi zorlaştıran ve bulaş hızını artıran faktörler karşısında alınan tedbirlerin yargı sistemi üzerindeki etkisi hakkında düzenlemelerin eleştirel bir bakışla değerlendirilmesi amaçlanmıştır. Temel hak ve hürriyetlere müdahalenin yoğun olduğu yargı düzenindeki işleyişi durduran kriz yönetimi sürecindeki faaliyetlerin yürütülmesinde birtakım düzenlemeler yapılmıştır. Söz konusu düzenlemelerden Cumhurbaşkanlığ Genelgesi, HSK tavsiye yazısı ve diğer düzenleyici işlemlerle alınan kararlar ve uygulamalar hakkında çalışma yapılmıştır. Çalışmada birden fazla araştırma yönteminden gözlem, sözlü görüşme, UYAP ve SEGBIS incelemeleri ile literatür araştırmalarına başvurulmuştur. Çalışma sirasında, Van Adalet Sarayı bünyesindeki mahkeme ve birimlerden güncel veriler alınmış, UYAP ve Segbis uygulamaları incelenerek dört başlık halinde çalışma yapmanın yanı sıra dijital hukukun geliştirilmesi ve yaygınlaşması yönünde yapılması gereken çalışmalar hakkında tespit ve önerilere de yer verilmiştir.
\end{abstract}

Keywords:

Digital Law,

Covid19,

Justice,

Legislation,

Judical System,

\section{ABSTRACT}

With this study; an evaluation on the topics which comprise of; at the beginning the fact that the new type of corona virus, which is thought to spread from the marine animal market in Wuhan, China and announced as a "pandemic" by the World Health Organization of the United Nations, has reached the dimension of a global disaster and the failure to find out the effective treatment for this epidemic; secondarily, completion of vaccination methods in long periods the existence of ossified relationships in social life and the measures taken by the management against the life styles that have become habitual is carried. Problems arising from some regulations such as Presidential Circular and HSK recommendation letter, which would halt the functioning of the judicial system where the interference with fundamental rights and freedoms is intense, has been identified. At the same time, it is aimed to critically evaluate the regulations which are related to the impact of the measures, which are taken over against the factors that make it difficult to combat the epidemic spreading all over the world and increase the speed of transmission, on the judicial system. In the study, from amoung more than one research methods, the observation, oral interview, UYAP and SEGBIS examinations and literature researches are refered. During the study, up-to-date data is obtained from courts and units within the Van Justice Palace, UYAP and Segbis practices were examined under four headings as well as that findings and suggestions about the studies that should be done so as to improve and spread digital law are also included.

\footnotetext{
* Bu çalışma 26-27 Ağustos 2020 tarihinde Paris'te gerçekleştirilen "2nd International Conference on Covid-19 Studies" kongresinde sözlü olarak sunulmuş olan bildirinin genişletilmiş ve güncellenmiş halidir.
} 


\section{GIRISS}

Kamu yönetiminde idarenin belirlediği politikaya, kalkınma planları, ekonomi, teknoloji, turizm, eğitim gibi olguların yanı sıra toplumdaki değişimlere paralel olarak esnek, uyarlanabilir programlar da dâhil edilir. Sağlık sektöründe ise, gelişecek bir olayın artan tıp teknolojisi karşısında olumsuz durum yaşatmayacağı ya da salgın olsa bile etkisinin dar alana nüfuz edeceği düşüncesi bir anda yayılan ve tüm sektörleri doğrudan etkileyen Covid-19 salgınını krize çevirmiştir. İlk olarak Çin'in Wuhan kentinde ortaya çıkan Covid-19, Çin sınırları dışına kısa sürede çıkmıș ve bütün dünya ülkelerinde ekonomi, eğitim, turizm ve sosyal hayattaki hareketliliği, insan alışkanlıklarını, günlük hayat rutinlerini durma noktasına getirmiştir. Bu durum, kamu yönetiminde, salgına karşı ulusal kaynakları aşacak nitelikte bir dizi önlemlerin alınmasını zorunlu kılmış; kamu kurumları ve özel sektör insan faktörünün olduğu her alanda salgının beklenmedik etkisi nedeniyle kısa sürede tedbirler almıştır.

Salgın ile mücadelede alınan tedbirlere bakıldığında, anayasal bir hak olarak nitelendirilen sağlıklı çevrede yaşama hakkı kapsamında devletin çeşitli önlemler aldığı görülmektedir (Şahbaz, 2010:410-412). Salgın sürecinde idare tarafından, toplum sağlığını korumak adına kaynakların seferber edildiği, alınan tedbirlerin kolay yayılım gösteren Covid-19 karşısında, hızlı şekilde uygulamaya konulduğu görülmek ile birlikte özellikle sosyal mesafenin sağlanması adına faaliyetlerin birçoğu durma noktasına gelmiştir.

Devlet yükümlülügünü yerine getirirken gerekli önlemleri alma ve alınan önlemlerin sonuçlarını öngörme bu kapsamda, bireylere sağlıklı ve kaliteli yaşam sunma; nitelikli yaşam şartlarına erişme imkânı da sağlamalıdır. Salgının yayılma ve öldürme etkisi, yasama ve yürütmeyi afet yönetimi sistemi ile daha hızlı ve acil karar almaya yönlendirmiş; aynı zamanda alınan kararların uygulanmasını sağlayacak kaynakların etkili ve verimli şekilde kullanılmasını gerektirmiştir. Salgınla mücadelede yargının işleyişinde de dava işlemlerinin ilerlemesi, duruşmaların durumu, sürelerin işlemesi gibi özellikler dikkate alınarak ülke genelinde sonuç verecek hizmetlere ilişkin birçok yasal düzenleme yapılmıştır.

Salgının tüm dünyayı olumsuz şekilde etkilemesi ve giderek yayılması karşısında Dünya Sağlık Örgütü tarafından Covid-19 salgını pandemi ilan edilmiştir (worlddometers.info, 2020). Pandemi ilan edilen bir durum karşısında salgının kontrol altına alınmasını sağlayan sosyal mesafe yasakları, maske takma zorunluluğu, sokağa çıkma yasağı, seyahat kısıtlamaları gibi önlemlerin temel noktası virüsün bulaş hızını ve yoğunluğunu düşürmek olmuştur. Bu kapsamda, yargı sisteminde salgınla mücadele amacıyla alınan önlemlerde adliye ortamlarındaki kalabalığı azaltmak ve sosyal mesafeyi korumak en başta gelmiştir. Kanun, Cumhurbaşkanlığı kararnameleri ve diğer düzenleyici işlemler salgının etkisini azaltmaya yönelik olsa da beraberinde birtakım sorunları getirmiştir.

\section{KAMU YÖNETIMINDE KRİZ YÖNETIMI}

Yönetim, iş birliği içinde, belirlenen amaç veya amaçların gerçekleştirilmesine yönelik yapılan grup faaliyetidir. (Eryılmaz, 2018:183-185) Kavram içeriğinde yer alan amaç, işbirliği ve grup faaliyeti, yönetimde örgütlenmeyi, plan yapmay1, süreci izlemeyi zorunlu hale getirmektedir. Kamunun da yönetim organizasyonu içerisinde amaçları gerçekleştirmek adına karar alırken ve uygularken gerekli araştırmaları ve incelemeleri yapması, süreci ve sonuçlarını öngörecek bir yol izlemesi, kaynakları etkin ve verimli kullanması yönetim kavramı ile doğrudan ilişkilidir. Özellikle kamu ihtiyaçlarının globalleşen dünya karşısında çeşitlenmesi ve artması ile birlikte yönetimin daha çabuk, etkin ve ulaşılabilir hizmetler vermesi zorunlu hale gelmiştir.

Dünyanın farklı yerlerinde meydana gelen olaylar artık tüm dünya üzerinde kriz yaratma etkisine sahiptir. (Aykaç, 2001:123-132) Nitekim Covid-19 salgını da olağanüstü bir durum ortaya çıkarmış tüm dünyada kriz etkisi yaratmıştır. İlk olarak Çin'de görülse de virüsten etkilenen ülkeler arasında İtalya ağır bilanço ile ilk sırada yer almış diğer ülkelere de yayılmıştır. Türkiye'de ise virüs kaynaklı ilk vaka 11.03.2020 tarihinde açıklanmıştır (TRT Haber). Covid-19'un Türkiye'de görülmesi üzerine kriz yönetimi politikası ile var olan yasal düzenlemelerin yanı sıra torba kanun, alt norm ve diğer düzenleyici işlemlerle karar ve tedbirler alınmıştır.

Salgının yarattığı kriz, yönetimi önlem almaya, sosyal ilişkileri azaltmaya çöken ekonomiye alternatif kaynaklar yaratmaya; işsiz kalanlara ve ticari işletmelere yönelik ekonomik paket hazırlamaya yönlendirmiştir. Ancak, idarenin kriz yönetimi sürecinde tedbirleri uygularken maddi ve beşeri kaynakları etkin şekilde kullanması ve sosyal devlet ilkesinin gereğini yerine getirmesi zorunludur. Ağır sonuçları bulunan salgın karşısında yargı işleyişinin büyük çoğunluğunda gerçekleştirilen durdurma ve erteleme kısa vadede yerinde görülmektedir. Bu süreçte, Ulusal Yargı A ̆g Projesi (UYAP), Ses ve Görüntü Bilişim Sistemi (SEGBİS) gibi dijital hukuk 
uygulamalarının etkin kullanılmadığı görülmektedir. Kriz ortamı üzerinden hukuk ilkeleri ve mevcut imkânlar ele alınmadan, ortaya çıkacak kişi temel hak ve hürriyetlerinin ihlali ve uzun vadeli etkileri düşünülmeden düzenleme yapılması kriz yönetiminde organizasyon eksikliğini ortaya çıkarmıştır. Örneğin, İcra İflas Kanununun (IїK) 330'uncu maddesinde takiplerin durdurulmasına ilişkin hüküm uygulandıktan sonra torba kanun ile bu hükmü geçersiz hale getiren geçici madde düzenlenmesi, konu hakkında mücbir sebep dışındaki alanlarda da düzenleme yapılması, icra takip işlemlerinin vatandaş yönünden durdurulması ancak kamu alacakları bakımından devam etmesi gibi düzenlemeler bu durumun göstergesidir.

\section{SALGIN İLE MÜCADELENIN YARGI SISTEMİNE ETKİSI}

Covid-19'un yarattığı kriz, insan faktörünün olduğu her alanda hareketsizliği ve durağanlaşmayı zorunlu hale getirmiştir. Yargı gibi süreklilik arz eden ve işleyişi yasal zeminde gerçekleşen alanlarda da yasal düzenlemeler ile tedbirler alınmıştır. Ancak, durdurma politikasına ilişkin düzenlemelerde, yargı sisteminde var olan dijital uygulamaların göz ardı edilerek hazırlanması, sürecin etkin ve verimli şekilde yürütülmemesine sebep olmuş uzun vadede hak ihlallerinin artması tehlikesine yol açmıştır.

\subsection{Yargı Sisteminin İşleyişine İlişskin Düzenlemeler}

Covid-19 kapsamında yargı sistemine ilişkin düzenlemeler, tedbirler, bu alanın yasa ile yürütülmesine binaen tedbirlerin de yasal düzlemde yapılmasını zorunlu kılmaktadır. Zira yargı düzenindeki işleyiş ve değişiklikler, yasa ile yürütülmektedir. Avrupa İnsan Hakları Sözleşmesi'nin 6. maddesinin 1.fikrasında (Information in Turkish, 2020);

"Her şahıs gerek medeni hak ve yükümlülükleriyle ilgili anlaşmazlıklar gerek cezai alanda kendisine yöneltilen suçlamalar hakkında karar verecek olan kanunla kurulmuş, bağımsız ve tarafsiz, bir mahkeme tarafindan, makul bir süre içerisinde, hakkaniyete uygun ve aleni surette dinlenmesini istemek hakkina sahiptir",

denilmektedir. Bu düzenlemede yer alan kavramlara bakıldığında, bireyin medeni hak ve yükümlülüklerinin, uyuşmazlıklarının ve ceza yargılamalarının kanunla kurulmuş mahkemeler tarafından adil yargılanma ilkesi doğrultusunda yargılanma hakkına sahip olduğu ifade edilmektedir. Buna göre, yargılama faaliyetleriyle ilgili iş ve işlemlerin yasal düzenleme ile yerine getirilmesi bireyin hukuki güvencesini sağlamak adına tanınan bir haktır. Covid-19 salgını sürecinde de düzenleyici işlemler ve tavsiye nitelikli kararlarla bulaş kaynağı insan faktörünün adliye ve diğer kurumlarda yarattığı insan sirkülasyonunun ve sosyal ilişkilerin azaltılması adına birtakım tedbirlerin yer aldığı düzenlemeler yapılmıştır.

İlk olarak 22.03.2020 gün ve 31076 say1l resmi gazetede yayımlanan 22.03.2020 tarih ve 2020/4 Say1l "Covid19 Kapsamında Kamu Çalışanlarına Yönelik Illave Tedbirler” ile ilgili Cumhurbaşkanlığı Genelgesinde, kamu hizmetlerini aksatmayacak şekilde ve ihtiyacı karşılayacak kadar asgari personelin bulundurulması şartıyla kamu görevlilerine uzaktan çalışma, dönüşümlü çalışma gibi esnek çalışma yöntemlerinin uygulanabileceği, Genelge kapsamında esnek çalışma yöntemlerinden faydalananlar ile idari izinli sayılanların görevlerini fiilen yerine getirmiş sayılacakları, daha önce Covid-19 kapsamında idari izinli sayılanların ise yeni bir karar verilinceye kadar idari izinlerinin devam edeceği ile esnek çalışmaya dair usul ve esasların ilgisine göre bakan, vali, belediye başkanı veya etkin üst yönetici tarafından belirleneceği ifade edilmiştir. Bu çerçevede; ivedi ve tutuklu işlemlerinin görülmesi amacıyla yeteri kadar hâkim, savcı ve personelin çalışmasını, diğer personellerin ise UYAP sistemi üzerinden davaların takiplerini temin edilecek çalışma ile evden devam edebilecekleri duyurulmuştur (Resmi Gazete, 2020).

Hâkim ve Savcılar Kurulu Genel Sekreterliği ise 'Covid-19 Kapsamında İlave Tedbirler' konulu yazı ile adliyelere görüş niteliğinde metin iletmiştir. Yazı içeriğinde, tutuklu işlere yönelik soruşturma ve kovuşturmalar ile ivedi sayllacak diğer hususlar haricinde duruşma ve keşiflerin ertelenmesi ile gerekli görülen hâllerde SEGBİS uygulamasının kullanılması, hâkim ve savcılara verilecek idari izinlerin kullandırılması ve personel sayısı azaltılarak nöbet usulü ile çalışmaların yapılması önerilmiştir. Ayrıca, nöbet sisteminde işlemlerin yapılmasını sağlamak amacıyla UYAP aracılığıyla evden çalışmaların sağlanması konusunda önerilerde bulunulmuştur (Hakimler ve Savcılar Kurulu , 2020). Ardından 26.03.2020 tarih ve 7226 sayılı Bazı Kanunlarda Değişiklik Yapılmasına Dair Kanun ile dava açma, icra takibi başlatma, başvuru, şikâyet, itiraz, ihtar, bildirim, ibraz ve zamanaşımı süreleri, hak düşürücü süreler ve zorunlu idari başvuru süreleri de dâhil olmak üzere bir hakkın doğumu, kullanımı veya sona ermesine ilişkin tüm süreler; 06.01.1982 tarihli ve 2577 sayılı İdari 
Yargılama Usulü Kanunu, 04.12.2004 tarihli ve 5271 sayılı Ceza Muhakemesi Kanunu ve 12.01.2011 tarihli ve 6100 sayılı Hukuk Muhakemeleri Kanunu ile usul hükmü içeren diğer kanunlarda taraflar bakımından belirlenen süreler ve bu kapsamda hâkim tarafindan tayin edilen süreler ile arabuluculuk ve uzlaştırma kurumlarındaki sürelerle ilgili düzenleme yapılmıştır.

Genelge kapsamında; "2004 sayılı İcra ve İflas Kanunu” ile takip hukukuna ilişkin diğer kanunlarda belirlenen süreler ve bu kapsamda hâkim veya icra ve iflas daireleri tarafindan tayin edilen süreler; nafaka alacaklarına ilişkin icra takipleri hariç olmak üzere tüm icra ve iflas takipleri, taraf ve takip işlemleri, yeni icra ve iflas takip taleplerinin alınması ve ihtiyati haciz kararlarının icra ve infazına ilişkin işlemler de 22.3.2020 tarihinden 30.04.2020 tarihine kadar durdurulmuştur. Söz konusu tarihler bilim kurulunun görüşü alınarak 29.04.2020 tarih ve 2480 sayılı Yarg1 Alanındaki Hak Kayıplarının Önlenmesi Amacıyla Getirilen Durma Süresinin Uzatılmasına Dair Karar ile 30.04.2020 tarihine kadar uzatılan sürelerin, 15.06.2020 tarihi de dâhil olmak üzere uzatılmasına karar verilmiştir (Resmi Gazete, 2020).

Bulaşın kolayca yayılacağı cezaevlerinde de salgını önlemek amacıyla Adalet Bakanlığı tarafından bir dizi karar ve tedbir alınmıştır. Buna göre tutuklu ve hükümlülerin mahkemeler arasındaki iletişiminin SEGBİS, UYAP gibi bilişim sistemleri aracılığıyla yapılacağı belirtilmiştir. Görüş, özel izin hakları, ceza infaz kurumları arasındaki nakiller, hastalık ve hükümlülerin denetimli serbestlik kapsamındaki kantin, lokanta gibi alanlardaki çalışmalarının ise ertelendiği görülmektedir. Aynı şekilde, anneleriyle birlikte kalan 0-6 yaş grubu çocukların kreş, anaokuluna gitmelerinin veya cezaevi dışındakilere teslim edilmeleri ertelenmiş; özel durumlarda ise görüşmelerin savcılık kanalıyla yapılabileceği belirtilmiştir. Söz konusu tedbirler, belirlenen sürelerin sonunda bilim kurulunun görüşü alınarak 15.05.2020 tarihine kadar uzatılmıştır (T.C. Adalet Bakanlığı Basın ve Halkla İlişkiler Müşavirliği, 2020). Ayrıca, cezaevlerinde yoğunluğun azaltılması adına 14.04.2020 Tarihli ve 7242 Sayılı Ceza ve Güvenlik Tedbirlerinin İnfazı Hakkında Kanun ile Bazı Kanunlarda Değişiklik Yapılmasına Dair Kanun çıkartılarak infaz kurumlarından salıverilme şartlarını hafifleten düzenlemelere de yer verilmiştir (Resmi Gazete, 2020).

Salgın ile mücadelede alınan kararlara bakıldığında, insan faktörünü azaltma, sosyal ilişkilerdeki çeşitliliği ve hareketliliği en aza indirme amacının olduğu, bu kapsamda sosyal mesafenin sağlandığı görülmektedir. Ancak, idarenin kriz yönetimi sürecinde tedbirleri uygulanmasında maddi ve beşeri kaynakların etkin şekilde kullanımı göz önünde bulundurulmalıdır (Eryılmaz, 2018:185). Covid-19 nedeniyle yargı sisteminin işleyişindeki düzenlemelerin ve uygulamaların mevcut sistemdeki UYAP ve SEGBİS gibi imkânlarla ve dijital hukuk anlayışı esas alınarak yapılması gerekirken durma politikasının izlenmesi beraberinde sorunlar getirmiştir. Nitekim yarg1 sistemindeki bulaş kaynağı insan faktörünün azaltılmasına yönelik alınan birçok tedbir ve uygulamaların adliye işleyişine, hukuk devleti ilkesine uygun olmadığı ve olası hak ihlallerine yol açtı̆̆ görülmektedir.

\subsection{Alınan Tedbirlerin Hukuki Düzenlemeler Karşısında Oluşturdukları Sorunlar}

Covid-19 sebebiyle yayımlanan Cumhurbaşkanlı̆̆ı Genelgesi doğrultusunda Hâkim ve Savcılar Kurulu tarafından tüm mahkemelerce duruşmaların ertelenmesi iş ve işlemlerin nöbet usulü ile yapılması, dosya taraflarının mazeretlerinin kabul edilmesi yönünde görüş bildirilmiştir. Görüş sonrası mahkemeler tarafından duruşmaların ertelenmesine, karar aşamasında olan dosya taraflarının karşılıklı muvafakati halinde ise dosya üzerinden karar verecekleri belirtilerek taraflara durum bildirir tebligat çıkartılmıştır. Bulaş hızı yüksek olan salgın karşısında, duruşmaların ertelenmesi kararı insan faktörünün azaltılması açısından doğru görülse de normalleşme dönemi ile mahkemelerde işlerin yığılmasına yol açacağı açık olup özellikle makul sürede yargılanma hakkının ihlaline yol açması kuvvetle muhtemeldir. Nitekim salgın öncesinde, Avrupa İnsan Hakları Mahkemesine (AİHM) Türkiye'nin taraf olduğu başvuruların birçoğu, adil yargılanma hakkı kapsamındaki makul sürede yargılanma hakkının ihlal edildiği yönünde sonuçlanmaktadır. AİHM kararlarındaki ihlal gerekçesi, iç hukuktaki düzenlemeler dışında; çoğunlukla kanunların uygulanması konusunda yargı sisteminin etkin ve verimli şekilde işlemediği yönünde olduğu görülmektedir. Diğer bir deyiş̧le, makul sürede yargılanma hakkının ihlal edilmesinde, Türkiye'deki yasal düzenlemelerin eksikliği veya yetersizliğinden ziyade yarg1 organlarının uygulamalarından kaynaklanan yanlışlıklardan olduğu görülmektedir (Erşen, 2007:138).

Covid-19 salgını nedeniyle UYAP veya SEGBİS gibi dijital hukuk alanlarının etkin ve verimli kullanılmaması, yargı işlemlerinin büyük çoğunluğunun durdurulması, bireyin makul sürede yargılanmamasına sebep olacağından adil yargılanma hakkının ihlaline yol açabileceği değerlendirilmektedir. Türkiye'de yasal düzenlemelere rağmen yargı sistemindeki ağır aksak işleyiş ve yanlış uygulamalar bireyin nihai kararı alacağına 
dair inancını da olumsuz etkilemektedir. Bu durumun, Avrupa İnsan Hakları Mahkemesi nezdinde Türkiye’yi ihlalci devlet konumuna getirmesi kaçınılmazdır.

Yargı sistematiğinde kamu ve özel hukuka ilişkin işlem sırası, 6100 Sayılı HMK, 5271 Sayılı CMK ve 2577 Sayılı IYUK ve diğer ilgili kanunlarda düzenlenmiştir. Mahkemeler, yargılama faaliyetinde usul işlemlerinin yasaya uygun şekilde ilerlemesini sağlamak ve takip etmekle görevlidirler (Pekcanıtez vd., 2016:215). Yargılamanın tarafı birey ise dava dosyalarının sonuçlanması adına kanuna uygun şekilde takip etmekte ve gerektiğinde avukatlardan hukuki yardım almaktadır. Yasal düzenlemeler doğrultusunda, dava dosyalarının ilerlemesi ise büyük ölçüde UYAP sistemi üzerinden gerçekleştirilmekte, fiziki takip daha çok duruşma işlemleri ile yapılmaktadır. UYAP üzerinden yapılan işlemlere bakıldığında dava açma, her türlü istinaf, temyiz, bilirkişi itiraz, beyan gibi dilekçeleri gönderme, dosyadan vazgeçme, feragat etme, duruşmalara mesleki ya da sağlık mazereti gönderme, dava harç ve masraflarını ödeme gibi birçok işlemi içermektedir. Ayrıca, adliye ile kamu kurumları ve özel sektörlerde e-tebligat yapılanlar arasında yazışmaların yapılması ve arşivlenmesi gibi işlemler de hızlandırılmaktadır (Karslı vd., 2009:3123-3133). UYAP, SEGBİS gibi dijital hukuk araçlarına covid-19 salgını sürecinde görüntülü ve sesli uygulamaların eklenerek geliştirilmesi hem sürece uygunluğu sağlayacak hem de yargılamaların sürüncemede bırakılmasını engelleyecektir (Uşaklığlu, 2020:115).

Yapılan düzenlemeler, duruşma yapılmaması sebebiyle ertelenen dosyaların dışında aynı tarihlerde işlemi yapılacak farklı dosyalar nedeniyle işlerin yığılmasına, dosyaların verimsiz şekilde incelenmesine, verilen kararlardaki usul ve esas yönünden hukuka aykırılıkların artmasına, olağan dönemde uzun süren yargılamaların olağanüstü dönemle birlikte daha fazla uzamasına ve makul sürenin aşılmasına yol açacaktır. UYAP veya SEGBİS'in geliştirilmesi yerine bu uygulamalar üzerinden yapılabilecek işlemlerin de ertelenmesi; salgın krizinin etkin şekilde yürütülmediğini göstermektedir.

\subsection{Covid-19 Salgın Tedbirlerinin Hukuki İlkelere Etkisi}

Cumhurbaşkanlığı Genelgesi ve diğer düzenleyici işlemlerle alınan tedbirlerin yasal dayanağının oluşturulması amacıyla 7226 sayılı Bazı Kanunlarda Değişiklik Yapılmasına Dair Kanun kabul edilmiştir. Anılı düzenleme ile dosya üzerinden karar verilmesinin önü açılmıştır. Ancak, bu uygulama Türk Ceza Hukuku sistemine ters düşmektedir. Kişi temel hak ve hürriyetine en fazla müdahalenin gerçekleştiği Ceza Hukuku alanında, yargılamaya esas alınan ilkelerden biri doğrudanlık ilkesidir. Doktrinde vasıtasızlık, yüzyüzelik ve doğrudan doğruyalık olarak adlandırılan doğrudanlık ilkesi, yargılamanın başlamasından sona ermesine kadarki süreçte tüm evrelerin karar verecek mahkeme heyeti tarafından doğrudan yapılması, araya başka bir vasıta veya birim girmeden incelenmesi, elde edilen delillerin araya fazla zaman girmeden sonuçlandırılması amacını gütmektedir (Arslan, 2014:136-138).

6100 Sayılı Hukuk Muhakemeleri Kanunu'nda da aynı şekilde yargılamada doğrudanlık ilkesinin uygulanması hüküm altına alınmıştır. Yasal düzenleme karşısında, olağanüstü hale dönüşen covid-19 salgını sürecinde, işlemlerin durdurulmasının yanı sıra yalnızca karar aşamasına gelmiş yargılamalarda, dosya üzerinden karar verilmesi usulen hukuka aykırıdır. $\mathrm{Bu}$ nedenle, usuli yönden oluşabilecek hukuka aykırılıkların önüne geçilebilmesi için UYAP sistemine görüntülü görüşme uygulaması eklenerek doğrudanlık ilkesinin sağlanması mümkün iken durma politikasının izlenmesi kanaatimizce yerinde bir uygulama değildir. Nitekim görüntülü ve sesli duruşma yöntemi ile tarafların adliye ortamına girmesi engellenecektir. Böylece salgının yayılması engellenebileceği gibi dava dosyalarının yığılma tehlikesi de ortadan kaldırılmış olacaktır. Türkiye'de e-devlet uygulaması ile entegreli UYAP sisteminden dava dosyalarının takip edilebilmesi nedeniyle hem vatandaşların hem de avukatların UYAP üzerinden mahkeme dosyasına erişim imkânlarının olduğu göz önünde bulundurulduğunda maliyeti yük olmayacak çalışmaların eklenmesi, sistemin geliştirilmesi etkinlik ve verimliliği arttıracaktır. UYAP gibi mahkeme işleyişini dijitalleştiren, kökleşmiş ve kullanımı yaygın bir sistem dururken kullanılmaması, işlemlerin ertelenmesi yargının iş yükünün daha da artmasına yol açacaktır. Uzaktan eğitimin ve uygulamaların çoğunlukla üniversiteler tarafından görüntülü yapıldığı, sistemin hızlıca uygulandığ 1 ve başarı sağladığı göz önünde bulundurulduğunda, yarg1 işlerinin durdurulması yarg1 yükünün daha da artmasına ve verimsizleşmesine yol açacaktır.

\subsection{Salgınla Mücadele Sürecinde İnfaz Değişikliği Yasasının Toplumdaki Etkileri}

14.04.2020 Tarihli ve 7242 Sayılı Ceza ve Güvenlik Tedbirlerinin İnfazı Hakkında Kanun ile Bazı Kanunlarda Değişiklik Yapılmasına Dair Kanun'da yapılan düzenlemede, infaz kurumlarından salıverilme şartları değiştirilmiştir. Koşullu salıverilme süreci, hükümlüye verilen cezanın ceza infaz kurumlarında kalınacak süreyi 
ifade etmektedir. Ancak bu sürenin, oransal olarak yansıtılması hesabına denetimli serbestlik uygulaması dâhil edilmemiştir. Denetimli serbestlik uygulaması da cezanın infaz hesabına dâhil edildiğinde, hükümlünün ceza infaz kurumunda geçirdiği süre daha da düşmektedir. Yasal düzenleme içeriğine bakıldığında, denetimli serbestlik uygulamasında değişikliğe gidildiği ve hükümlülerin bir kısmının hükme esas cezayı infaz kurumunda geçirmeden salıverildiği değerlendirilmiştir. Yapılan düzenleme ile cezaevlerinin yoğunluğunun azaltılarak olası bir bulaş durumunda bireyleri koruma adına önemli bir değiş̧iklik olduğu kabul edilebilir. Ancak, düzenleme içeriğinin bir kısım hükümlüleri kapsamaması düzenlemenin eşitlik ilkesine açıç̧a aykırı olmasına yol açmaktadır. İnfaz rejimi, yararlanması gereken kişiler bakımından ayrım gözetilmeksizin uygulanmalıdır. Suç politikasında alınan kararların, yalnızca işlenen suç niteliği yönünden uygulanması hukuk ilkeleri ile bağdaşmamaktadır. Nitekim salgınla mücadelede infaz yasasında yapılan değişiklikten yalnızca belli suçtan hüküm giymiş kişilerin yararlanması Anayasanın 10. Maddesinde düzenlenen eşitlik ilkesine aykırılık teşkil etmektedir. Bu nedenle, infaz yasasındaki değişikliğin salgınla mücadele kapsamında değerlendirilmesi olanaksızdır. Adalet Bakanlığının ceza ve infaz kurumlarındaki izin, nakil, görüş gibi konuları geçici süre ertelediğine ilişkin düzenlemesi doğrultusunda hükümlü ve tutukluların yakınları ve avukatlarıyla görüntülü görüşme imkânı sağlanabilir. İnfaz Kanununda yapılacak değişiklik yerine ceza yargılamalarında olağan dönemde kullanılan SEGBİS'in salgın sırasında kullanılmaması, geliştirilmemesi kriz yönetiminin etkili şekilde yürütülmediğini, alınan kararların panik ortamında ve kısa vadeli etkileri düşünülen kararlar olduğunu göstermektedir.

\section{5. İcra ve İflas İşlemlerinin Durdurulması Sebebiyle Ortaya Çıkan Sorunlar}

Covid-19 salgını sürecinde Cumhurbaşkanlığı tarafından İcra İflas Kanununun 330. Maddesindeki; "salgın hastalı, umumi bir musibet veya harp halinde Cumhurbaşkanı kararlyla memleketin bir kısmında veya bazı iktisadi zümreler lehine muayyen bir müddet için icra takipleri durdurulabilir", düzenlemesi ile salgın hastalık nedeniyle takiplerin durdurulmasına ilişkin hükmün uygulanması kararı alınmıştır. Ancak sonrasında, 22.03.2020 gün ve 31076 sayılı Resmi Gazetede yayımlanan 2279 sayılı Cumhurbaşkanlığ genelgesi ile icra iflas konularında nerdeyse tüm işlemleri durdurmaya yönelik bir uygulama kabul edilmiştir. Bu düzenleme ile icra iflas işlerinde başlayan takiplerin durdurulmasının yanı sıra daha spesifik konularda da durma yönünde düzenleme yapıldığı görülmektedir. Nitekim İcra ve İflas Kanununda düzenlenen işlemlerden, ''İcra ve İflas takipleri, 09.06.1932 tarihli ve 2004 sayılı İcra ve İflas Kanunu ile takip hukukuna ilişkin diğer kanunlarda belirlenen süreler ve bu kapsamda hâkim veya icra ve iflas daireleri tarafindan tayin edilen süreler; nafaka alacaklarına ilişkin icra takipleri hariç olmak üzere tüm icra ve iflas takipleri, taraf ve takip işlemleri, yeni icra ve iflas takip taleplerinin alınması, ihtiyati haciz kararlarının icra ve infazına ilişkin işlemler 22.03.2020 (bu tarih dâhil) tarihinden itibaren 30.04.2020 tarihine kadar durdurulmuştur (Resmi Gazete, 2020).

Adliyelerde yer alan icra daireleri, iş yükünün en fazla olduğu, dosya ve işlem sirkülasyonun en fazla görüldüğü alandır. Yeni tip korona virüsünün yayılmasının azaltılması ise bütün ülkelerde yapılan sosyal mesafenin sağlanması ile mümkün olmuştur. Bu nedenle, yalnızca birkaç işlem dışında iş yapılmaması etkili ve yerinde bir yöntemdir. İcra takip işlemlerine bakıldığında, taraflar arasında anayasal hak olan mülkiyet hakkı, eşitlik ilkesi gibi temel haklar haciz ve satış işlemleri ile etkilenmektedir (Akkaya, 2009:260). Ancak, icra işlemlerinin durdurulması salgını önlerken alacaklı tarafın etkili ve etkin yargılanma hakkının ihlaline yol açmakta ve borçluların bu süreçten yararlanmasına sebep olmaktadır.

Alınan önlemlerin hem alacaklı tarafı hem borçlu tarafı koruyan; taraflar arasında dengeli en azından alacaklı tarafın zarara uğramasını engelleyecek şekilde olması yerinde olacaktır. Söz gelimi icra takibi başlatılan borçlular, genellikle malvarlıklarını alacaklıdan kaçırma adına üçüncü kişilere devrederler. Borçlunun iyi niyetli üçüncü kişilere malvarlığı devri halinde, alacaklı taraf dosya takibinde başarı sağlasa bile borçlu adına kayıtlı malvarlığı bulunmadığında tahsil yapması adeta imkânsız hale gelmektedir. Dosya ve avukat masrafi, yargılama giderleri de ayrıca kendisine yükletilmekte hukuk önünde hak arama yoluna gitmesi ile zarara uğramaktadır. Bu durum, hukuki güvenirliği olumsuz etkilediği gibi Anayasanın 36. maddesinde düzenlenen hak arama hürriyetini de bertaraf etmektedir. Bu nedenle alınan tedbirler karşısında taşınmaz, araç, banka hesapları devri gibi işlemler durdurulmadığından hakkında icra takibi başlatılan borçlu tarafın bu malvarlıklarını covid-19 salgını sürecinde rahatlıkla devretmesi mümkündür. Yapılan yasal düzenleme adeta borçlulara zaman tanımakta, malvarlıklarını alacaklılardan kaçırma imkânı vermektedir. Borçlu tarafın malvarlığını devri halinde ise alacaklarının zararı da katlanmaktadır. Buna karşın hakkında icra takibi başlatılan borçluların mal devrinin de durdurulması taraflar arasındaki eşit işlem koşulunun sağlanmasına katkı sunacaktır. Bankaların dahi kolaylıkla hakkında icra takibi bulunan vatandaşların icra bilgilerine erişebildiği göz önünde bulundurulduğunda noterlerin 
veya tapu müdürlüklerinin, devir talebinde bulunan kişilerin icra bilgilerine bakarak işlemleri yapması taşınmaz, araç gibi malvarlıklarının kaçırılması sorununu ortadan bir nebze de olsa kaldırılmasını sağlayabilecektir.

Ayrıca, yapılan düzenlemede her ne kadar vatandaş alacakları için icra ve iflas takip iş ve işlemlerinin durdurulmasına karar verilmişse de kamu alacakları bu düzenlemenin dışında tutulmuştur. Covid-19 salgın sürecinin kriz etkisi doğurması üzerine tüm dünya ülkelerinde alınan kararların ve tedbirlerin odak noktası, insan faktörünün yarattığ 1 kalabalık ve temasın önlenmesidir. Bu durumda, kamunun vatandaş alacağ1 yönünden cebri icra yolunu kapatması karşısında kamu alacakları yönünden sınırlama getirmemesi toplum nezdinde salgınla mücadeledeki inancı olumsuz etkileyen bir olgudur. Devletin kamu gücüne ek olarak zamansal ve öncelikli kazanımı, diğer alacaklılara göre alacağı tahsil etme imkânı vermektedir. Bu durum, hukuk düzeninde kamu alacakları ve vatandaş alacakları arasında eşitsizlik yaratan, sosyal hukuk devleti ilkesine aykırılık oluşturan bir durumdur (Özekes, 2020:7).

\subsection{Tutuklu İncelemelerin Dosya Üzerinden Yapılması Sorunu}

Tutukluluğun incelenmesine ilişkin yasal düzenleme, 5271 sayılı Ceza Muhakemesi Kanunu'nun 108. Maddesinde yer almıştır. Yasal düzenleme doğrultusunda, tutukluluğun incelenmesi, 30 günlük sürelerle re'sen veya talep halinde mahkemelerce değerlendirilmektedir. Anılı hükme göre, şüpheli veya sanığın tutuklu bulunduğu süre zarfında en geç otuzar günlük sürelerle tutukluluk halinin gözden geçirilmesi ve tutuklama şartlarının devam edip etmediğinin incelenmesi gerekmektedir.

Salgınla mücadele kapsamında alınan tedbirlerde her ne kadar tutuklu işler harici tutulmuşsa da mahkemelerin tutukluluk incelemelerini dosya üzerinden sanık veya şüpheli ile farklı ortamlarda bulunarak SEGBİS aracılığıyla usulen incelediği ve çoğunlukla tutukluluğun devamına karar verildiği görülmektedir. Tutuklama tedbiri kişi temel hak ve özgürlüklerine en fazla müdahaleye sebep olan tedbirlerdendir. Tutuklama tedbiri istisna olup esas olan serbest yargılamadır. Bu nedenle, bir kimsenin tutuklu yargılanmasına karar verilmesi için Türk Ceza Kanunu Madde 100'de belirtilen şartların varlığı ile mahkemenin takdir yetkisi dâhilinde değerlendirme yapılması gerekir. Tutukluluk halinin covid-19 sebebiyle şüpheli veya sanık olmadan dosya üzerinden incelenmesi de serbest yargılanması gereken kişiler bakımından hak ihlalidir. Nitekim yasal düzenlemede gerek soruşturma gerek kovuşturma aşamalarında tutukluluk hâlinin devamının gerekip gerekmeyeceği hususunun, merciince belirli aralıklarla mutlaka incelenmesi zorunlu tutulmuştur. İncelemeyi yapacak hâkimin tutuklu kişiyi görmeden, bu kişi ile doğrudan yargılama yapmadan takdir yetkisini tarafsız ve objektif şekilde kullanması da olanaksızdır.

\section{SONUÇ}

Beklenmedik şekilde gelişen ve hızlı yayılan salgın, tüm dünya ülkelerinde ekonomik, siyasi, kültürel, sosyal ilişkiler kısaca insan faktörünün olduğu her alanda etkisini göstermiştir. Beklenmedik yayılma hızı, süreci krize çevirmiş ve dünya ülkelerini tedbir ve önlem almaya yönlendirmiştir. Ancak, kriz yönetiminde organizasyon varlığı sürecin başarı ile sonuçlanmasında zorunlu hale gelmiştir. Özellikle kısa vadede alınacak tedbirlerin sonuçlarının öngörülmesi kaynakların verimli ve etki şekilde kullanılması, en az hasarla covid-19 salgın sürecinin atlatılması esas amaç olmalıdır.

Ülkemizde yargı sistemi ile ilgili alınan tedbirlerde ise insan etkenini azaltma, buna bağlı işlemleri durdurma politikası izlendiği görülmektedir. Kişi temel hak ve hürriyetlerinin tanındığı ve korunduğu yargı sisteminde panik düzenlemelerin kısa vadede covid-19'un yayılımını engellese de uzun vadede sorunlar ortaya çıaracağ 1 açıktır. Özellikle ertelenen işlemlerin süre bakımından sonradan yapılacak işlemlerle birlikte yığılması makul sürede yargılanma hakkını; infaz rejimi ve İcra İflas Kanununda yapılan değişiklikler eşitlik ilkesini, dosya üzerinden karar verilmesi ise adil yargılanma hakkı gibi temel hakları ihlal niteliğindedir. Bu durum, Türkiye'nin AİHM ve Anayasa Mahkemesi nezdinde sorumluluğunu doğurabilir. Buna karşın, UYAP ve SEGBİS uygulamalarına görüntülü ve sesli görüşmenin eklenerek devreye girmesi yargı işleyişinin sürekliliğini sağlayacaktır.

Dijital hukuk anlayışı yerine yargı sistemini durdurmak kriz yönetiminin uygulanmasında yargı sistemi açısından idarece beklenen sonuçları doğurmayacaktır. Dijital hukukun UYAP ve SEGBİS gibi kullanımı yaygın, kökleşmiş uygulamalar üzerinden yapılması salgının yayılım hızını azaltacağı gibi yargılama sürecindeki maliyeti de düşürecektir. Bu yöndeki uygulamaların ve hukuk vasıtalarının devreye girmesi ile yığılmaların ve hak kayıplarının önüne geçilebilecektir. 
YILDIRIMVURAN, Seyyal, MILANLIOĞLI, Ulaş Koray ve ÇAKAN, Suat - Covid-19 Pandemi Sürecinin Türk Yargı Sistemine Etkileri

Kanun, Cumhurbaşkanlığı genelgesi ve diğer düzenleyici işlemlerinin, hukuk ilkeleri gözetilerek ve mevcut yap1 gözlemlenerek uzaktan yargılama işleyişini geliştirecek, dijitalleşme sürecine uygun teknik çalışmalarla desteklenmesi adliye ortamındaki insan faktörünü bitirmese de önemli ölçüde azaltacaktır. Bu nedenle yargı işleyişindeki sistemde, salgın öncesinde 'dijital adliye' vasfını gören UYAP ve SEGBİS sisteminin aktif kullanılması ve geliştirilmesi ülkemiz açısından diğer ülke uygulamalarına nazaran büyük bir fark oluşturacaktır.

\section{KAYNAKÇA}

AKKAYA, Tolga (2009), "İcra Memurunun Haczedilmezlik Kurallarını Kendiliğinden Dikkate Alıp Alamayacağı Sorunu”, Dokuz Eylül Üniversitesi Hukuk Fakültesi Dergisi, S.11(3), ss.845-866.

ARSLAN, Aziz Serkan (2014), “Doğrudanlık Illkesi”, Süleyman Demirel Üniversitesi Hukuk Fakültesi Dergisi, S.4(2), ss.133-144.

AYKAÇ, Burhan (2001), "Kamu Yönetiminde Kriz ve Kriz Yönetimi”, Gazi Üniversitesi İktisadi ve İdari Bilimler Fakültesi, S.3(2), ss.123-132.

ERŞEN, Serkan (2007), “Avrupa İnsan Hakları Sözleşmesi ve Türk Hukukunda Adil Yargılanma Hakkı”, Yayınlanmamış Yüksek Lisans Tezi, Kırıkkale Üniversitesi Sosyal Bilimler Enstitüsü, Kırıkkale.

ERYILMAZ, Bilal (2018), Kamu Yönetimi, Seçkin Yayıncılık, Ankara.

KARSLI, Abdurrahman, GÜRSUL, Fatih ve KARTAL, Elif (2009), "Nitel Araştırma: Avukatların Ulusal Yargı Ăğ Projesi (UYAP) Uygulama Yazılımına İlişkin Görüşleri”, Legal Hukuk Dergisi, S.7(82), ss.3123-3133.

ÖZEKES, Muhammed (2020), Covid-19 Salgının Hukuki Boyutu, On İki Levha Yayıncılık, İstanbul.

PEKCANITEZ, Hakan, ATALAY, Oğuz ve ÖZEKES, Muhammed (2016), Medeni Usul Hukuku, Seçkin Yayınc1lık, Ankara.

ŞAHBAZ, İbrahim (2010), “Bir Sosyal Hak Olarak Sağlık Hakkı”, Türkiye Barolar Birliği Dergisi, S.86, ss.405-423.

UŞAKLIOĞLU, Ahmet Yavuz (2020), Dijital Hukuk, Seçkin Yayıncılık, Ankara.

http://www.worlddometers.info (Erişim Tarihi: 20.06.2020).

https://basin.adalet.gov.tr/ceza-infaz-kurumlarinda-koronavirus-tedbirleri-15-mayisa-kadar-uzatildi

(Erişim

Tarihi: 20.06.2020).

https://www.echr.coe.int/documents/convention_tur.pdf (Erişim Tarihi: 05.07.2020).

https://www.hsk.gov.tr/Eklentiler/Dosyalar/f275097a-aef5-4b51-b98d-c7b69ceb3b9f.pdf （Erişim Tarihi: 23.05.2020).

https://www.hsk.gov.tr/Eklentiler/files/uu.pdf (Erişim Tarihi: 30.06.2020).

https://www.resmigazete.gov.tr/eskiler/2020/03/20200322-2.pdf (Erişim Tarihi: 01.07.2020).

https://www.resmigazete.gov.tr/eskiler/2020/03/20200322M1.pdf (Erişim Tarihi: 01.07.2020).

https://www.resmigazete.gov.tr/eskiler/2020/04/20200415-16.htm (Erişim Tarihi: 01.07.2020).

https://www.resmigazete.gov.tr/eskiler/2020/04/20200430.pdf (Erişim Tarihi: 01.07.2020).

https://www.trthaber.com/haber/gundem/turkiyede-ilk-koronavirus-vakasi-tespit-edildi-466216.html

Tarihi: 23.05.2020).

(Erişim 